\title{
The Role of Absorptive Capacity in Innovation and Productivity in Chilean Companies: An Adapted CDM Model Across Industries
}

\author{
Juan Acevedo ${ }^{1^{*}}$, Iván Díaz-Molina
}

\begin{abstract}
Drawing on an adapted CDM model, we present evidence on the role of strategic and operational absorptive capacity on innovation and productivity across industries in developing economies. Using a pooled cross-sectional sample from Chilean innovation surveys, we find that greater absorptive capacity (ACAP) helps firms to increase their innovative investment and the probability of producing technological innovations, which then increases firms' labor productivity. Additionally, the effect of the strategic dimension is stronger than the operational dimension aspect, which means that the strategy of reaching these external sources might be more important than the skill of a firm' internal units to acquire and transform external information. We find that while strategic ACAP is a stronger predictor of investment and technological innovation in both manufacturing and services companies, but operational ACAP has differing effects.
\end{abstract}

Keywords: innovation, absorptive capacity, productivity, CDM model

Submitted: August $30^{\text {th }}, 2021 /$ Approved: December $10^{\text {th }}, 2021$

\section{Introduction}

Recent economic growth in Latin America has been largely under-researched in comparison to other regions, with stagnant productivity levels presenting the most urgent challenge (Crespi, Tacsir \& Vargas., 2016; Alvarez \& Grazzi, 2018; Zahler, Goya \& Caamano, 2018). Consequently, research has suggested the importance of innovation to improve productivity, applying technological advances to lead to more effective use of productive resources, and the transformation of new ideas into new economic solutions (Crespi \& Zuñiga, 2012).

Latin American's emerging markets differ from developed markets in their innovation pursuits. For example, Latin America relies more on imitation and technology acquisition rather than R\&D; engages in exploitation over exploration tasks; pursues less product innovation; and lacks many developed innovation networks (Geldes \& Felzensztein, 2013; Ketelhöhn \& Ogliastri, 2013; Geldes, Felzensztein \& Palacios, 2017). In this region, most studies have measured innovation behavior through inputs such as R\&D or innovation expenditure and outcomes such as innovation performance or technological innovation.

Alvarez and Grazzi (2018) identified that the dominant methodology used to examine the relationships among these variables has been Crepon-Duguet-Miresse (CDM) model (Crepon, Duguet \& Mairesse, 1998). This model has been used in more than 40 countries, being the most appropriate model when analyzing microdata based on the Oslo Manual (Lööf, Mairesse \& Mohnenc, 2017; OECD, 2005). The CDM model is a structural model of the main variables impacting firm innovation. Following the baseline model, there are four equations: (1) The firm' decision to invest in innovation; (2) the intensity of the investment in innovation; (3) the knowledge production function linking innovation intensity and innovation outcomes; and (4) the output production function, in which firm productivity is a function of innovation outcomes and other control variables. In addition, using the CDM model offers an advantage when dealing with the problems of selectivity bias and endogeneity in the functions of innovation and productivity.

In recent decades, several studies (Zahra \& George, 2002; Del Carpio \& Miralles, 2018; Schmidt \& Rammer, 2006; Lau \& Lo, 2015; Chen \& Chang, 2012; Ortigueira-Sánchez et al., 2020) have analyzed the positive effect of absorptive capacity (ACAP) on the product, process, organizational, and marketing innovations. However, despite the importance of absorptive capacity in the innovation process, there has been little quantitative research focused on the effect of absorptive capacity on innovation investment and productivity using the CDM model. While previous studies of ACAP in developing countries have supported its positive effect on innovation, they have done so without addressing endogeneity problems.

Based on an adapted CDM model, this paper presents evidence about the role of strategic and operational absorptive capacity on firm decisions to invest in innovation activities, technological innovation, and productivity for developing economies. Specifically, we conduct three surveys across a sample of Chilean firms to examine the relationships between innovation and productivity across the manufacturing, service, and agricultural/extractive industries.

By comparing industries in developing countries, we gain insight into how the innovation process differs across sectors and geographical areas (Crossan \& Apaydin, 2010). Likewise, there is not a consensus about innovative behavior among industries. Geldes, Felzensztein \& Palacios (2017) indicate that product innovation affects innovation performance across industries, and Alvarez, Bravo-Ortega \& Zahler (2015) find similar determinants of technological innovation in manufacturing and service Chilean firms.

(1) Centro de innovación y Emprendimiento, ESE Business School, Universidad de Los Andes

${ }^{*}$ Corresponding author: jacevedo.ese@uandes.cl 
Chile is an excellent context in which to examine this issue. Often considered the most competitive country in the Latin American, Chile is also the most innovative country in the region, ranking $53^{\text {rd }}$ in the Global Index of Innovation (WIPO, 2021). However, as a typical emerging economy, it focuses on primary-products export where innovation does not play a very relevant role and contributes relatively little direct value to its economy.

Results study provide insight into the relevant role of ACAP in the innovation process, addressing endogeneity problems through the CDM model. First, we find that strategic and operational absorptive capacity have positive and significant effects on expenditure and the probability of producing technological innovation outcomes, meanwhile, its effects on labor productivity were indirect through the positive impact of innovation investment and technological innovation. This issue contributes to our understanding of how ACAP plays a relevant role to correct the inefficient use of $R \& D$ that hinders the development of radical innovation and has a higher impact on international markets (Crespi and Zuñiga, 2012).

Second, the study highlights the specific behavior of strategic and operational absorptive capacity across industries. Comparing manufacturing and services companies, strategic ACAP is a stronger predictor of investment and technological innovation in both sectors, but operational ACAP has different effects. Alvarez et al. (2015) observed that the service sector shows very similar behavior to the manufacturing sector in innovation inputs, outputs, and productivity determinants. Therefore, operational absorptive capacity might be a more relevant variable to study differences among industries.

Third, we confirm the importance of measuring absorptive capacity from a multidimensional perspective. We find that ACAP, as measured through its strategic and operational dimensions, suggests that the strategy of reaching these external sources and the skill of internal units to acquire and transform external information are variables that had not been before in the CDM model, but they are critical to understanding innovation processes.

The rest of the paper is structured as follows. The second section provides a brief overview of the literature and includes the hypotheses relating to absorptive capacity and innovation. The third section outlines the quantitative methodology used for the study and presents sample descriptive statistics. Next, the study's econometric results are presented along with a discussion and conclusions.

\section{Literature Review}

\subsection{CDM review}

The CDM model has become the most important method for measuring innovation and productivity, being used to examine over 40 countries. This structural model explains how research investment connects to innovation output and by extension productivity, and it suggests a method of correcting for the selectivity and the endogeneity inherent to many innovation studies. According to Lööf, Mairesse \& Mohnenc (2017), this methodology is most appropriate to analyze and study innovation survey data based on the Oslo Manual (OECD, 2005), which is the guideline for innovation surveys conducted by members of the European Union and countries within the OECD.

Crespi \& Zuñiga (2012) examined five Latin American countries using the CDM model and found that firms investing in R\&D have greater capabilities for introducing new technological advances. Additionally, they found that those firms that engage in innovation have a greater impact on their productivity than those that do not. Additionally, the determinants of innovation investment are much more heterogeneous in developing countries than in OECD countries: Firm size increases the probability of investing in innovation, whereas exporting, being part of a multinational, and receiving public support positively impact investment for some but not all.

Tello (2015) recognizes different results for developed and developing countries. In developed countries, intense $R \& D$ investment is a strong predictor of improving innovation - products, process innovation, or patents (Lööf \& Heshmati, 2002; Lööf et al., 2003; Janz, Loof \& Peters 2004; Van Leeuwen \& Klomp, 2006; OECD, 2009). However, Tello observed mixed conclusions about how R\&D transforms into innovation in developing markets. Following Tello, studies such as Pérez, Dutrenit \& Barceinas (2005), Chudnovsky, Lopez, \& Pupato (2006), and Benavente (2006) failed to find any significant effect of innovation on firms' productivity in Argentinean and Mexican firms, meanwhile, in Chile, the size and market share increase the probability of R\&D investment, but not the intensity of R\&D.

Regarding the innovation capabilities of manufacturing firms in Chile, previous studies (Alvarez, Bravo-Ortega \& Navarro; 2011) have confirmed the importance of firm size as well as cooperation with universities and technology centers for increasing the probability of R\&D investment. Simultaneously, R\&D investment intensity increases the probability of introducing new products, but it does not impact new processes.

Comparing manufacturing and service companies, there is evidence that exporting, patent protection, and firm size affect the decision to invest in innovation across both sectors, meanwhile exporting and cooperation are a stronger prediction of innovation intensity and technological innovation (Alvarez, Bravo-Ortega \& Zahler; 2015).

Finally, Alvarez \& Grazzi (2018) argued that there is a substantial discrepancy in the specification of the equations to analyze innovation using the CDM model, which makes it difficult to recognize the main factors of innovation in Latin American economies. Even studies with common specifications across countries such as Crespi \& $\mathrm{Zu}$ ñiga (2012) have identified different determinants for each economy. For this reason, previous research has suggested that there are several challenges in terms of creative identification strategies for looking at causal determinants of innovation, especially those related to barriers such as lack of competition and human capital. 


\subsection{Absorptive Capacity at the Strategic and Operational Level of the Organization}

The concept of absorptive capacity (ACAP) is defined as a firm's ability to learn from external knowledge through processes of knowledge identification, assimilation, and exploitation (Cohen \& Levinthal, 1990). This concept has been linked to the use of intangible assets as knowledge, which are remarked as a driver of a firm' performance (Harris \& Lee, 2018; Eustace, 2000; Corrado et. al., 2011; Haskel, 2015). Several studies have emphasized the importance of absorptive capacity for increasing a company' productivity. Patel, Terjesen \& Li, (2012) argued that this capacity creates organizational competencies and cultivates sources of competitive advantage; Tu et al. (2006) indicated that ACAP improves the ability to implement new manufacturing practices; some research focuses on the cooperation with supply chain partners (Zacharia, Nix \& Lusch; 2011), and acquire supply chain technology (Autry et al., 2010). Vlačić et al. (2019) suggested that higher levels of ACAP could positively influence business performance in technology-driven firms that regularly perform R\&D activities.

Previous research has measured absorptive capacity multidimensionally rather than using a proxy like R\&D or human capital for the construct. Zahra \& George (2002) argued that ACAP can be broken down into two dimensions: i) potential capacity which comprises knowledge acquisition and assimilation, and ii) realized capacity that transforms the assimilated knowledge to the already established exploitation ability. These two dimensions have been identified as complementary, interrelated, and necessary (Harris \& Lee, 2018).

Yan, Yu \& Dong (2016) and Diaz-Molina (2018) suggested that the concept of strategic absorptive capacity from an organizational learning perspective could be linked to Zahra and George's (2002) potential capacity. Absorptive capacity is associated with strategic learning and mechanisms of the firm to use external knowledge as input for dealing with radical and incremental innovation. Connecting to the realized capacity dimension, some studies (Patel, Terjesen \& Li, 2012; Diaz-Molina, 2018) suggested an operational absorptive capacity which is described by authors such as the skill of a firm' internal units to acquire, assimilate, transform, and exploit external information. Moreover, this dimension expanded beyond its innovation focus on efficiency and productivity, being observed not only from R\&D but to all functional areas of an organization.

This study applies the strategic and operational dimensions of ACAP, which include the distinctive effects of potential and realized ACAP, to the CDM model.

\subsection{The impact of absorptive capacity on innovation in developing countries}

Many studies have analyzed the positive effect of absorptive capacity on product, process, organizational, or marketing innovations in developed countries (Zahra \& George, 2002; Schmidt \& Rammer, 2006; Chen \& Chang, 2012; Garcia-Morales, Moreno \& Llorens-Montes 2007; Vlačić et al., 2019). However, it is difficult to generalize the results obtained from developed economies to developing economies.
These economies experience different obstacles to innovation, such as late adoption; emphasis on technology acquisition over R\&D; emphasis on exploitation over exploration tasks; and lower product innovation (Geldes \& Felzensztein, 2013; Geldes, Felzensztein \& Palacios, 2017; Crespi \& Zuñiga 2012).

In addition, despite the importance of the absorptive capacity for the innovation process, few quantitative studies have focused on the effect of ACAP on innovation and productivity using the CDM model (Gombau \& Segarra, 2011; Howell, 2017). Although some research has been carried out on innovation and productivity using the CDM model in Latin American economies (Crespi \& Zuñiga, 2012; Alvarez, Bravo-Ortega \& Navarro, 2011; Tello, 2015; Brown \& Guzmán; 2014; Raffo, Lhuillery \& Miotti., 2008), few studies have focused on the role of absorptive capacity. This is unfortunate, as Crespi and Zuñiga (2012) argue that the failure of R\&D to correlate significantly with innovation outcomes and productivity in developing countries could be explained by being far from the technological frontier and having weak or no incentives to invest in innovation. Moreover, the few studies of developing countries that found support for the positive effect of ACAP on innovation have done so without controlling by endogeneity in innovation and productivity (Del Carpio \& Miralles, 2018).

Given the literature review and considering the limited literature in this line of research, this study explores whether absorptive capacity supports the development of innovation and productivity in emerging economies using the CDM model. In other words, do the strategic and operational dimensions of absorptive capacity improve i) the amount or intensity of innovation investment, 2) innovation outcomes, and 3) productivity of firms?

Cohen and Levinthal (1989) found that ACAP affects R\&D expenditures such as learning incentives. In other words, the greater the quantity of knowledge to be assimilated and exploited, the greater will be the incentive for R\&D spending. Therefore, efforts to reach outside the organization for new knowledge acts like a learning environment that triggers investment - the strategic dimension. Additionally, the ability of a firm' units to transform, and exploit external knowledge initiate attempts to spend on training, best practices, and reward systems for incremental improvements - the operational dimension.

To advance knowledge of the association between absorptive capacity and the innovation investment of firms, the following hypothesis is proposed:

H1. Strategic absorptive capacity increases the innovation investment of firms

H2. Operational absorptive capacity increases the innovation investment of firms

On the other hand, Lau \& Lo (2015) remarked that absorptive capacity helps to make changes in the organizational culture, $R \& D$ investment, and diffusion channels, consequently improving organizational innovation. Additionally, acquisition and assimilation 
capabilities help firms identify sources of new external knowledge, which opens the firm's cognitive schemas and grants awareness of radical innovations that transform industries (Cohen and Levinthal, 1989). Transformation capability helps the firm develop new perceptual schema and change existing processes (Zahra \& George, 2002) and assists in developing new product ideas with new information, while exploitation capability converts knowledge into new products (Gao et al., 2008). Thus, we defined the following hypothesis:

H3. Strategic absorptive capacity increases innovations outputs of firms

H4. Operational absorptive capacity increases the innovations outputs of firms

Based on Tello (2015), Alvarez, Bravo-Ortega \& Zahler (2015), and Crespi \& Zuñiga (2012), we analyze the indirect effect of absorptive capacity through the measure of the effects of expenditure in innovation and innovation outputs on labor productivity. Thus, the following hypothesis is tested:

H5. Expenditure of expenditure in innovation increases labor productivity of firms

H6. Innovation outputs of expenditure in innovation increase the labor productivity of firms.

In addition, it is particularly critical how innovative process differs across sectors and geographical areas (Crossan \& Apaydin, 2010). Likewise, Geldes, Felzensztein \& Palacios (2017) indicate that product innovation affects innovation performance across industries, meanwhile, Alvarez, Bravo-Ortega \& Zahler (2015) find similar determinants of technological innovation in Chilean manufacturing and service firms. According to this, our study tests hypotheses across industries to examine differences among manufacturing, service, and agricultural/extractive companies.

\section{Methodology}

\subsection{Study' background: Innovation in Chile}

The barriers to innovation in emerging markets such as Latin American countries differ from those of developed markets. These barriers include socio-political uncertainty, low compliance with laws, the existence of an informal economy, and a strong reliance on interpersonal ties, networking, or partnership alliances (Geldes, Felzensztein \& Palacios, 2017). These differences make it difficult to directly map the innovation patterns in Latin America onto those of more developed markets, and vice-versa.

To extend existent knowledge about innovation and absorptive capacity in emerging countries, we study the case of Chile, one of four OECD member countries in Latin America. Chile's economy is both the most competitive in this region and the most innovative, ranking $53^{\text {rd }}$ on the Global Index of Innovation (WIPO, 2021). Likewise, the Chilean economy is estimated at USD279,885 million, placing it among the world's 50 largest economies (World Bank, 2021). Nevertheless, as an emerging economy, Chile focuses on exporting primary products, which involved little innovation. According to OECD/Eurostat (2020), this country presents $24 \%$ of innovative firms while OECD countries average $49 \%$; meanwhile, technological innovation is $18 \%$ and $40 \%$ in Chile and OECD countries respectively. Additionally, Chile shares several innovation-related problems with the region. Specifically, they tend to adopt innovation later than developed countries; focus on imitation and technology acquisition rather than R\&D; engage in exploitation rather than exploration tasks; pursue less product innovation, and lack coordination with national innovation systems or innovation networks (Geldes \& Felzensztein, 2013; Geldes, Felzensztein \& Palacios, 2017).

\subsection{Sampling and data collection}

Our main source of data is the Innovation Survey carried every two years by the Chilean National Institute of Statistics (INE) and the Chilean Ministry of Economy. Eleven rounds of the survey have been undertaken between 1994 and 2018. Following several previous studies (Zahler, Goya \& Caamano, 2018; Alvarez, Bravo-Ortega \& Zahler, 2015), we use a pooled cross-sectional sample of the $9^{\text {th }}, 10^{\text {th }}$, and $11^{\text {th }}$ surveys - which cover the years 2013-14, 2015-16 and 2017-18, respectively - to expand the sample size while maintaining methodological consistency. Therefore, our data set includes data from a pooled, cross-sectional sample of 17,457 Chilean companies.

These surveys, with some small variations, have maintained standardized questions according to the Oslo Manual (OECD, 2005) and thus can be used effectively in comparing estimations over time. It is important to indicate that we do not undertake panel estimations because the number of cases decreases significantly, varying substantially from surveys and concentrating on larger firms.

\subsection{Estimation methodology}

The CDM model is a structural model that compares the main variables of the process of innovation of firms. Following the baseline model, we use an adapted CDM model with four equations: (1) The firm' decision to invest in innovation; (2) the intensity of innovation investment; (3) the knowledge production function linking innovation intensity and innovation outcomes; and (4) the output production function, in which firm productivity is a function of innovation outcomes and other control variables. Through these equations, the CDM model addresses the problem of selectivity bias and endogeneity in the functions of innovation and productivity.

Using our adapted CDM model, we explore several hypotheses related to the impact of strategic and operational absorptive capacity on dependent variables.

Following specifications suggested by Crespi and Zuñiga (2012) and Alvarez et al (2015), we estimate Equations 1 and 2 using a generalized Tobit that considers the decision to invest and the amount invested in innovation. For Equation 3, we use the predicted value of innovation intensity as an explanatory variable in the knowledgeproduction function, where the innovation outcome is measured by a categorical variable that accounts for technological innovations, 
either product or process. Finally, for Equation 4, the predicted values of innovation outcomes are used as explanatory variables in the output production function.

\subsubsection{Absorptive capacity}

The theoretical variable examined in this study is absorptive capacity, defined as the ability to learn from external knowledge through knowledge identification, assimilation, and exploitation (Cohen \& Levinthal, 1990). Zahra and George (2002) reconceptualize this term as a firm' dynamic capability about knowledge acquisition, assimilation, transformation, and application to gain and sustain a competitive advantage.

There are many measures of ACAP. Harris, Krenz, and Moffat (2021) examined several proxies about this concept, identifying different perspectives. Some studies concentrate on $R \& D$ investment, $R \& D$ department or R\&D employees (Cohen \& Levinthal, 1990; Veugelers, 1997; Huang et al., 2015); meanwhile, other authors analyze measures of human capital measures, e.g., number of employees with an undergraduate, masters, or doctoral degree (Crescenzi \& Gagliardi, 2018; Xia \& Roper, 2008). In addition, some approaches concentrate on combined measures of the use of knowledge from external sources (Arbussa \& Coenders, 2007; Harris \& Li, 2009; Harris \&Yan, 2019; Murovec \& Prodan, 2009).

We use Díaz-Molina's model (2018) which defined two dimensions of absorptive capacity, which are related to the potential and realized capacity theorized by Zahra and George (2002): i) strategic absorptive capacity, which is associated with strategic learning and the ability to use and integrate external knowledge to acquire a competitive advantage; and ii) operational absorptive capacity, which is linked to the firm's ability to reach outside its boundaries for operational knowledge (i.e., engineering, operational, information systems).

Strategic absorptive capacity was derived from a factor analysis conducted on a set of questions from the survey addressing the external sources to which firms reach out to engage in innovation activities. These external sources are classified as suppliers, customers, competitors, consultants, universities, research facilities, conferences, publications, professional associations, and the internet. Answers to these ten questions were dichotomous. Thus, a polychoric procedure was conducted before the factor analysis. The results were rotated for a better fit, and factors with an eigenvalue higher than 1.0 were retained, covering $94 \%$ of the total variance.

Because Chile's Innovation Survey as our data asks no direct question related to operational absorptive capacity, we use a proxy following Setia and Patel (2013). Specifically, we assume that certain firms have established engineering and information systems departments that may reach out to other institutions or firms to learn about state-ofthe-art practices in their respective areas as a means to improve operations. Following this, we use a dummy variable to measure operational absorptive capacity that has a value equal to 1 when the firm has departments in at least one of these categories: engineering, R\&D, or IS.
Table 1 summarizes the resulting loadings for each relevant factor. Despite lower communalities, strategic absorptive capacity presents a higher Cronbach' Alpha (0.86), indicating high reliability. Additionally, this construct is similar to other studies on the effect of external sources on innovation (Harris \& Le, 2019; Harris \& Li, 2009; Harris \& Yan, 2019).

Table 1. Factor analysis for strategic absorptive capacity

\begin{tabular}{lcc}
\hline & \multicolumn{2}{c}{ Strategic Absorptive Capacity } \\
Loading \\
$\begin{array}{l}\text { Survey Item } \\
\text { External Market Sources of }\end{array}$ & Factor 1 & Communality \\
Information: & & 0.31 \\
\hline Suppliers & 0.83 & 0.27 \\
Customers & 0.85 & 0.32 \\
Competitors & 0.82 & 0.28 \\
Consultants & 0.84 & \\
External Institutional & & 0.27 \\
Sources of Information: & & 0.30 \\
Universities & 0.85 & \\
Research Institutes & 0.83 & \\
External Other Sources of & & 0.16 \\
Information: & & 0.17 \\
Conferences & 0.91 & 0.23 \\
Publications & 0.90 & 0.14 \\
Professional Associations & 0.87 & \\
Internet & 0.92 & \\
Eigenvalue & 7.51 & \\
\% of Total Variance & 94 & \\
Cronbach' Alpha & 0.86 & \\
\hline
\end{tabular}

\subsubsection{Innovation Investment}

The generalized Tobit or Heckman maximum likelihood estimators to model the decision to invest and the amount invested in Innovation are linked to Equation 1 - the decision to invest in innovationand Equation 2 - the amount of investment -.The regression equation account for firms' innovative effort $I E_{i}^{*}$ (Figure 1), which is a latent variable, where $X^{\prime}{ }_{1}$ is a determinant of innovation effort; $\beta$ is a vector of parameters of interest; and $\boldsymbol{e}_{\text {... is in }}$ is error term. The proxy of IE is measured by the (log) expenditures on innovation activities per worker.

$$
I E_{i}^{*}=X_{1 i}^{\prime} \beta+e_{i} \quad(\text { Figure } 1)
$$

If firms report innovative expenditures, it is the risk of selection bias. Instead, Crespi and Zuñiga (2012) assume that whether the firm decides to do innovation investment or not (Figure 2), where $I D_{i}$ is is an innovation decision binary endogenous variable equal to zero for firms that do not invest in innovation and equal to one if it spends resources in innovation; $I D_{i}^{*}$ is a corresponding latent variable such that firms decide to invest in innovation if it is above a certain threshold denoted by c ; and $\mathrm{W}$ is a vector of explanatory variables. 
$I D_{i}=1$ if $I D_{i}^{*}=\mathrm{W}+\alpha+e_{i}>c$, and 0 otherwise (Figure 2)

Therefore, conditional on firm i engaging in innovation activities, the observed the amount innovation investment (IEi ) is given by Figure 3 , where $X^{\prime}{ }_{1}$ is a determinant of innovation effort; $\beta$ is a vector of parameters of interest; and $e_{\text {.... }}$ is an error term. The proxy of IE is measured by the (log) expenditures on innovation activities per worker.

$I E_{i}^{*}=X_{i}^{\prime} \beta+e_{i}$ if $I D_{i}=1$, and 0 otherwise if $I D_{i}=0$ (Figure 3)

The firm' decision to invest in innovation activities ( $1=$ yes, $0=$ no) is controlled by explanatory variables such as export which is defined as a dummy variable for exporters; size which is the number of workers (in logs); foreign ownership is a dummy variable for foreign-owned firms; and patent protection which is other dummy for those firms that filed for a patent in the previous period.

For innovation intensity - log expenditures on innovation activities per worker-, we include as explanatory variables: strategic and operational absorptive capacity, export, size, foreign ownership, patent protection, cooperation - dummy variable for firms that have some cooperative arrangement on innovation activities- public financial support - dummy variable that indicates whether the firm uses public resources for funding R\&D investments- and survey period -time of survey application-.

\subsubsection{Knowledge or Innovation Production Function}

The next equation in the adapted CDM model is the knowledge or innovation production function, where dependent variable for innovation output is a dummy variable that indicating whether the firm declares having introduced either a product or process innovation (Crespi \& Zuñiga, 2012; Alvarez, Bravo-Ortega \& Zahler, 2015; Tello, 2015). Therefore, we use the following probit regression (Figure 4):

$$
T I_{i}=I E_{i}^{*} \delta+Y^{\prime} \gamma+\mu_{i}(\text { Figure } 4)
$$

where TIi is knowledge outputs by technological innovation, $I E_{i}^{*}$ is the predicted value of the firm' innovative effort from the estimated generalized Tobit equations described above, is a vector of explanatory variables and $\mu_{i}$ is an error term. As well as in Tobit equations, strategic and operational absorptive capacity are included as explanatory variables. Additionally, we use control variables such as firm size, public finance, exporting, foreign ownership and survey period. The introduction of predicted value of the firm' innovative effort is a mechanism to deal with the potential endogeneity of innovation investment.

\subsubsection{Output-Production Function}

Based on Alvarez et al. (2015), last equation relates innovation to labor productivity assuming a Cobb-Douglas production function as follows:

$$
\gamma_{i}=\alpha_{i} k_{1}+\alpha_{i} I_{1}+\mu_{i} \text { (Figure 5) }
$$

where y is labor productivity - log of real sales per worker-; $\mathrm{k}$ is capital stock per worker; $\mathrm{I}$ is the innovation outcome and $\mu_{i}$ is an error term. To deal with the endogeneity of the innovation variable, we include the predicted values of innovation outputs and innovation inputs as innovation expenditure. There is a lack information about capital stock or investment, for this reason, we included new equipment investment as explanatory variable. In addition, we use size, new equipment and survey period.

\section{Results}

Table 2 presents descriptive statistics for the innovation variables divided by sector. As found in other Latin American countries, innovation is carried out in very few companies. Specifically, we observe that $18.3 \%$ of the sample engages in technological innovation $-8.9 \%$ in product innovation and $14.9 \%$ in process innovation -manufacturing firms have more propensity to innovate. However, non-technological innovation presents similar rates between manufacturing and services companies ( $15.7 \%$ and $14 \%$ respectively). Regarding innovation inputs, $43.7 \%$ of the surveyed firms present a percentage of total expenditure on innovation activities, being manufacturing firms have more propensity to innovate than other sectors.

Furthermore, we observe that $17.3 \%$ of the sample has developed actions related to strategic absorptive capacity, which means that they engage with external knowledge as an input for dealing with radical and incremental innovation. In addition, operational absorptive capacity presents in a higher proportion of the sample at $27.0 \%$, indicating that more companies intend to develop internal units for acquiring, assimilating, transforming, and exploiting external information. Across both dimensions, manufacturing firms have higher innovation-related percentages than those in other industries.

Regarding our control variables, $12.8 \%$ of companies export goods, mainly in the manufacturing industry, meanwhile cooperation on innovation activities only represents $4.1 \%$. 
Table 2: Descriptive statistics

\begin{tabular}{|c|c|c|c|c|}
\hline Product Innovation & $12.1 \%$ & $8.2 \%$ & $5.2 \%$ & $8.9 \%$ \\
\hline Process Innovation & $18.4 \%$ & $13.5 \%$ & $14.2 \%$ & $14.9 \%$ \\
\hline Organizational Innovation & $12.1 \%$ & $10.8 \%$ & $6.9 \%$ & $10.7 \%$ \\
\hline Technological Innovation & $22.6 \%$ & $16.7 \%$ & $16.1 \%$ & $18.3 \%$ \\
\hline Non- Technological Innovation & $15.7 \%$ & $14.0 \%$ & $8.4 \%$ & $13.9 \%$ \\
\hline $\begin{array}{l}\text { Expenditure on } \\
\text { Innovation activities }\end{array}$ & $54.1 \%$ & $40.5 \%$ & $36.1 \%$ & $43.7 \%$ \\
\hline Operational absorptive capacity & $34.2 \%$ & $26.3 \%$ & $13.6 \%$ & $27.0 \%$ \\
\hline Firm Size (mean) & 164.3 & 198.4 & 125.4 & 180.4 \\
\hline Exporting & $23.9 \%$ & $6.9 \%$ & $16.9 \%$ & $12.8 \%$ \\
\hline Log Labor productivity (mean) & 10.7 & 10.8 & 10.7 & 10.7 \\
\hline Cooperation & $5.5 \%$ & $3.6 \%$ & $3.4 \%$ & $4.1 \%$ \\
\hline Public financial support & $4.9 \%$ & $3.1 \%$ & $4.1 \%$ & $3.7 \%$ \\
\hline Foreign ownership & $8.3 \%$ & $6.9 \%$ & $5.5 \%$ & $7.1 \%$ \\
\hline
\end{tabular}

Notes: Innovation survey data, waves 9, 10, and 11. Chilean Ministry of Economy

Table 3 presents the Heckman estimated results for the determinants of the likelihood to engage within the firm and the intensity of this expenditure - the log of innovation expenditure per worker. We find that size, being an exporter, and the use of patent protection positively affect the probability of engaging in innovation investment, which is similar to previous Chilean and Latin American investigations (Crespi \& Zuñiga 2012; Alvarez, Bravo-Ortega \& Zahler, 2015; Tello, 2015; Brown \& Guzmán; 2014).

We also identify several positive and significant predictors of innovation intensity, such as being an exporter, public financial support, and patent protection. Absorptive capacity plays a positive role in innovation intensity: The coefficients for strategic and operational absorptive capacity are positive and significant for the dependent variable. However, its impact is different across sectors: Strategic absorptive capacity has a great impact on manufacturing and services firms, whereas operational absorptive capacity is a strong predictor only for services companies. Overall, this finding supports Hypothesis 1 and Hypothesis 2 about strategic and operational absorptive capacity increasing the innovation investment of firms.
Table 4 shows results for the innovation output equation - the probability of introducing technological innovation. Findings indicate that innovation intensity and size are important factors that increase the probability that firms will develop innovative output. Coherent with previous evidence from Alvarez et al (2015), exports and foreign ownership have negative and significant effects on innovation output. In addition, innovation intensity appears to have greater predictive strength for manufacturing than other industries.

Additionally, we observe that strategic and operational absorptive capacity impact technological innovation across all sectors, excepting services sector to operational dimension, supporting Hypotheses 3 and 4. The effect of the strategic dimension is stronger than that of the operational dimension, indicating that the strategy of reaching out to external sources is more important than the skill with which a firm's internal units acquire and transform external information. This finding is consistent with Del Carpio and Miralles (2018), though our study also considers the potential endogeneity of innovation investment. 
Table 3. Probability of investing in innovation (ID) and intensity of innovation expenditure per employee (IE)

\begin{tabular}{|c|c|c|c|c|}
\hline \multirow{3}{*}{ Variables } & \multicolumn{4}{|c|}{ 9th, 10th, and 11th Innovation Surveys 2013-2018 } \\
\hline & (1) & (2) & (3) & (4) \\
\hline & Manufacturing & Services & Agricultural/Extractive & Total \\
\hline \multicolumn{5}{|c|}{ Selection (prob of spending in innov) } \\
\hline \multirow[t]{2}{*}{ Exporting } & $0.32^{* * *}$ & $0.25^{\star * *}$ & $0.37^{* * *}$ & $0.32^{\star * *}$ \\
\hline & $(0.05)$ & $(0.06)$ & $(0.04)$ & $(0.03)$ \\
\hline \multirow[t]{2}{*}{ Foreign } & $0.20^{* * *}$ & -0.05 & -0.15 & 0.03 \\
\hline & $(0.07)$ & $(0.06)$ & $(0.15)$ & $(0.04)$ \\
\hline \multirow[t]{2}{*}{ Size } & $0.24^{\star * *}$ & $0.17^{\star * *}$ & $0.18^{\star * *}$ & $0.18^{\star * *}$ \\
\hline & $(0.01)$ & $(0.01)$ & $(0.02)$ & $(0.01)$ \\
\hline \multirow[t]{2}{*}{ Patent protection } & $1.09^{* * *}$ & $0.92^{* * *}$ & $1.06^{* * *}$ & $1.14^{* * *}$ \\
\hline & $(0.10)$ & $(0.08)$ & $(0.34)$ & $(0.07)$ \\
\hline \multicolumn{5}{|c|}{ Intensity (log amount spend in innov per employee) } \\
\hline \multirow[t]{2}{*}{ Exporting } & $0.60^{* * *}$ & $0.79^{* * *}$ & $1.25^{* * *}$ & $0.93^{* * *}$ \\
\hline & $(0.13)$ & $(0.20)$ & $(0.34)$ & $(0.10)$ \\
\hline \multirow[t]{2}{*}{ Foreign } & $0.38^{* *}$ & $0.52^{* *}$ & 0.63 & $0.45^{* * *}$ \\
\hline & $(0.17)$ & $(0.20)$ & $(0.47)$ & $(0.13)$ \\
\hline \multirow[t]{2}{*}{ Public financial support } & $0.31^{\star * *}$ & $0.45^{\star *}$ & 0.19 & $0.44^{* * *}$ \\
\hline & $(0.14)$ & $(0.45)$ & $(0.25)$ & $(0.09)$ \\
\hline \multirow[t]{2}{*}{ Patent protection } & $0.59^{\star * *}$ & $2.12^{\star * *}$ & $1.09^{*}$ & $2.25^{\star *}$ \\
\hline & $(0.20)$ & $(0.26)$ & $(0.56)$ & $(0.19)$ \\
\hline \multirow[t]{2}{*}{ Co-operation in $\mathrm{R} \& \mathrm{D}$} & 0.03 & 0.18 & -0.36 & 0.09 \\
\hline & $(0.13)$ & $(0.13)$ & $(0.33)$ & $(0.09)$ \\
\hline \multirow[t]{2}{*}{ Strategic absorptive capacity } & $0.88^{\star * *}$ & $0.95^{\star * *}$ & 0.76 & $0.94^{* * *}$ \\
\hline & $(0.21)$ & $(0.19)$ & $(0.48)$ & $(0.14)$ \\
\hline \multirow[t]{2}{*}{ Operational absorptive capacity } & -0.02 & $0.43^{* * *}$ & 0.06 & $0.24^{* * *}$ \\
\hline & $(0.12)$ & $(0.10)$ & $(0.28)$ & $(0.08)$ \\
\hline Observations & 4,786 & 10,014 & 1,931 & 16,733 \\
\hline
\end{tabular}

Notes: Innovation survey data, waves 9,10 , and 11 . Firm-level pooled Heckmann regressions controlling for survey. ${ }^{* *} \mathrm{p}<0.01,{ }^{\star *} \mathrm{p}<0.5,{ }^{\star} \mathrm{p}<0.1$.

Table 4. Probability of Technological Innovation, (TI: introduction of product or process innovation)

\begin{tabular}{|c|c|c|c|c|}
\hline & $\begin{array}{c}\text { (1) } \\
\text { Manufacturing }\end{array}$ & (2) Services & $\begin{array}{c}(3) \\
\text { Agricultural/Extractive }\end{array}$ & (4) Total \\
\hline \multirow[t]{2}{*}{ Constant } & $-6.82^{* * *}$ & $-1.51^{* * *}$ & $-3.13^{\star *}$ & $-1.95^{\star * *}$ \\
\hline & $(1.77)$ & $(0.05)$ & $(1.21)$ & $(0.09)$ \\
\hline \multirow[t]{2}{*}{ IE_p (predicted Inn exp per employee) } & $4,34^{\star * *}$ & $1.13^{* * *}$ & 1.64 & $0.97^{\star * *}$ \\
\hline & $(1.41)$ & $(0.20)$ & $(1.49)$ & $(0.15)$ \\
\hline \multirow[t]{2}{*}{ Size } & $0.09^{* * *}$ & $0.06^{* * *}$ & $0.08^{* * *}$ & $0.07^{\star * *}$ \\
\hline & $(0.02)$ & $(0.01)$ & $(0.03)$ & $(0.01)$ \\
\hline \multirow[t]{2}{*}{ Exporting } & $-0.68^{\star * *}$ & $-0.47^{\star * *}$ & -0.57 & $-0.31^{* * *}$ \\
\hline & $(0.22)$ & $(0.10)$ & $(0.56)$ & $(0.06)$ \\
\hline \multirow[t]{2}{*}{ Foreign } & $-0.26^{*}$ & $-0.31^{\star * *}$ & $-0.70^{\star *}$ & $-0.27^{\star * *}$ \\
\hline & $(0.12)$ & $(0.08)$ & $(0.33)$ & $(0.06)$ \\
\hline \multirow[t]{2}{*}{ Public financial support } & -0.01 & -0.05 & 0.30 & 0.11 \\
\hline & $(0.17)$ & $(0.12)$ & $(0.25)$ & $(0.08)$ \\
\hline \multirow[t]{2}{*}{ Strategic absorptive capacity } & $2.92^{\star * *}$ & $2.99^{* * *}$ & $3.92^{* * *}$ & $3.35^{\star * *}$ \\
\hline & $(0.38)$ & $(0.19)$ & $(0.52)$ & $(0.14)$ \\
\hline \multirow[t]{2}{*}{ Operational absorptive capacity } & $0.43^{\star * *}$ & 0.04 & $0.28^{\star *}$ & $0.24^{* * *}$ \\
\hline & $(0.05)$ & $(0.06)$ & $(0.13)$ & $(0.03)$ \\
\hline Log pseudo-likelihood & -1.701 .7 & $-3,371.7$ & -584.9 & $-5,683.7$ \\
\hline Adj. R-Squared & 0.34 & 0.27 & 0.33 & 0.29 \\
\hline Observations & 4,786 & 10,011 & 1,931 & 16,733 \\
\hline
\end{tabular}

Notes: Innovation survey data, waves 9,10 and 11 . Firm level pooled Probit regressions controlling for survey. ${ }^{\star * *} \mathrm{p}<0.01,{ }^{\star *} \mathrm{p}<0.5,{ }^{\star} \mathrm{p}<0.1$. 
Finally, Table 5 regression coefficients of the labor productivity (TFP) reports that the predicted values of innovation intensity and innovation inputs are statistically significant and lead to higher TFP performance. This finding supports Hypotheses 5 and 6 about the indirect effect of absorptive capacity on labor productivity through expenditure in innovation and innovation outputs. Interestingly, we find that non-technological innovation is a stronger positive determinant of TFP when analyzing the effect of innovation outputs. Moreover, we find that technological innovation and innovation intensity results appear to be more important for manufacturing than for service and agricultural/extractive companies, whereas non-technological innovation appears to have a similar impact for all firms.

\section{Discussions}

Our findings are consistent with the broader CDM empirical literature in developing countries (Crespi \& Zuñiga, 2012; Tello, 2015; Alvarez et al., 2011; Alvarez et al.,2015); Specifically, we find that firm size, being an exporter, and use of patent protection positively impact the probability of engaging in innovation investment, meanwhile these predictors and public finances are significant for innovation investment. For technological innovation, predicted innovation intensity and size are important factors for increasing the probability to develop innovative output. In addition, we confirm the positive impact of innovation input on labor productivity through the effects of nontechnological innovation as well as the predicted values of innovation intensity and technological innovation inputs.

Regarding our theoretical hypotheses, we find that absorptive capacity appears to help firms increase their investment in innovative activities and thus the probability of producing technological innovation outcomes. Additionally, the observed effects of ACAP on labor productivity were indirect, operating through the positive effects of IE and technological innovation on TFP, particularly for manufacturing firms. Therefore, results confirm the importance of absorptive capacity in the virtuous circle in which R\&D spending, innovation, and productivity are interconnected, especially the strategic dimension.

Table 5. The impact of innovation on labor productivity (Y: log sales per employee)

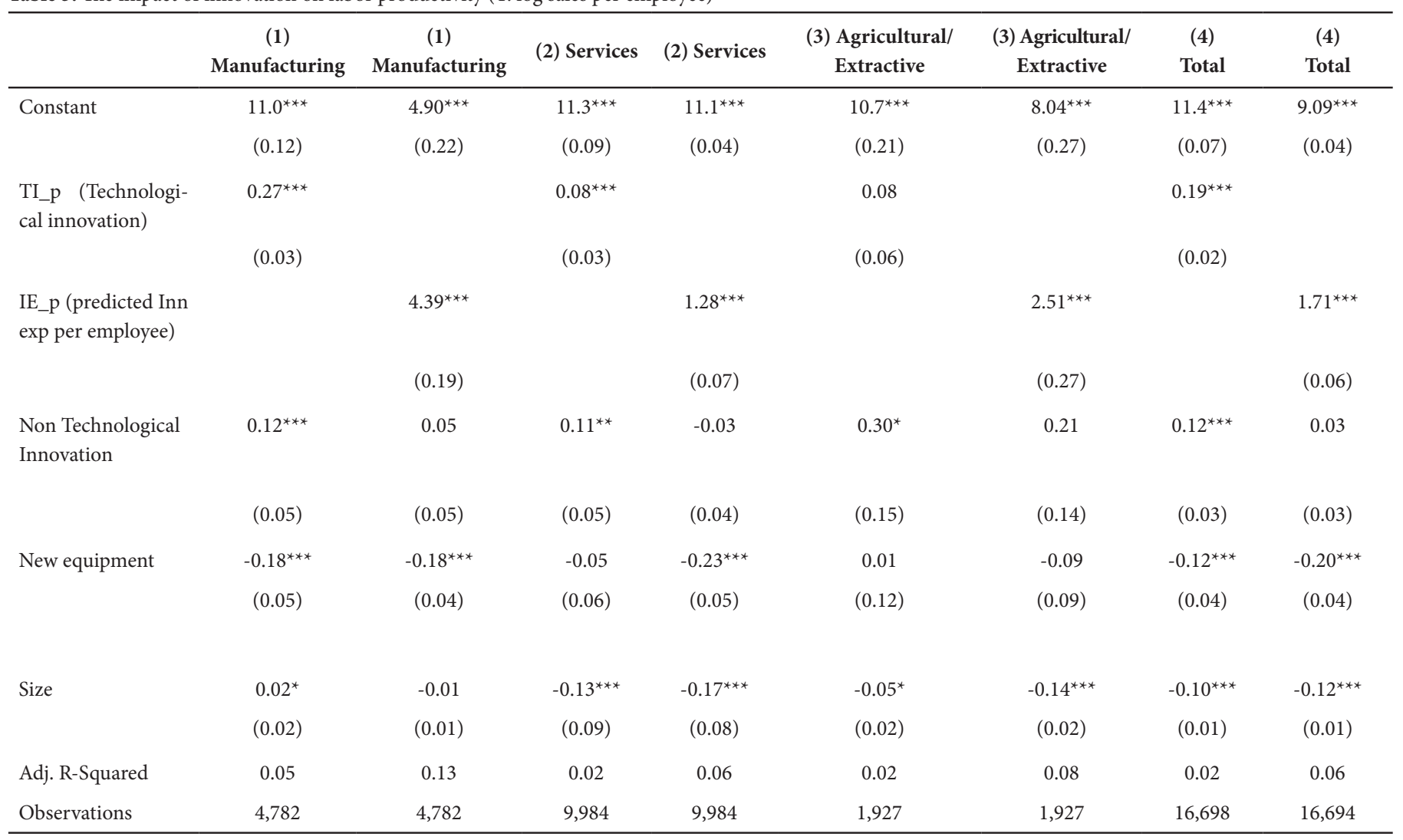

Notes: Innovation survey data, waves 9, 10, and 11. Firm-level pooled OLS regressions controlling for the survey.

${ }^{* * *} \mathrm{p}<0.01,{ }^{* *} \mathrm{p}<0.5,{ }^{*} \mathrm{p}<0.1$. 
In addition, the effect of the strategic dimension is stronger than the operational dimension aspect, which means that the strategy of reaching these external sources should be more important than the skill of a firm' internal units to acquire and transform external information. In developing economies, reaching external knowledge seems to be more critical than operational efficiency for improving innovativeness performance.

Finally, based on some studies which suggest different innovative across sectors (Crossan \& Apaydin, 2010; Geldes, Felzensztein \& Palacios, 2017), we identified some differences among industries. Regarding innovation intensity, strategic absorptive capacity has a positive impact on manufacturing and services firms, meanwhile operational absorptive capacity is a stronger predictor only on services companies. Technological innovation presents a positive impact of operational ACAP in manufacturing and agricultural/extractive firms, meanwhile, strategic ACAP has a stronger effect on all industries especially the agricultural/extractive sector-.

Coherent with previous evidence from Alvarez, Bravo-Ortega \& Zahler (2015), the impact of innovation intensity on technological innovation appears to be stronger for manufacturing than other industries. The impact of non-technological innovation and innovation intensity on productivity seems to be more important for manufacturing than for service and agricultural/extractive companies. Non- technological innovation presents a similar impact for all firms.

\section{Conclusions, implications, and limitations}

Despite previous studies have discussed the relation between innovation and productivity in developing countries using the CDM model (Crespi \& Zuñiga, 2012; Alvarez, Bravo-Ortega \& Navarro; 2011; Tello, 2015; Brown \& Guzmán; 2014; Raffo, Lhuillery \& Miotti., 2008; Edeh \& Acedo, 2021; Alvarez, Bravo-Ortega \& Zahler, 2015), there is still very little evidence explaining the role of absorptive capacity (ACAP) across industries. This paper filled this gap by examining whether the strategic and operational dimensions of absorptive capacity improve the amount or intensity of innovation investment, innovation outcomes, and productivity in firms. Using a pooled cross-sectional sample of 17,457 Chilean companies, this study uncovers valuable information about an under-researched region and serves as a contrast with traditional literature which frequently focuses only on developed countries. This contribution is seemed crucial when Crespi and Zuñiga (2012) argue that the failure of R\&D to correlate significantly with innovation outcomes and productivity in developing countries could be explained by countries being too far from the technological frontier and relevant incentives to invest in innovation being weak or absent.

\subsection{Implications for theory}

Our study makes several theoretical contributions. First, our findings fill a crucial gap in our knowledge about the relations among ACAP, innovation, and productivity as understood by the CDM model. Specifically, we find that ACAP affects R\&D expenditures, such as learning incentives, and improves organizational innovation, thereby helping to change organizational culture, increase R\&D investment, and leverage diffusion channels (Lau \& Lo, 2015).
Second, the study confirms the importance of measuring absorptive capacity from a multidimensional perspective. We draw on DíazMolina's (2018) model outlining the two dimensions of absorptive capacity - strategic and operational capacity - and find the importance of reaching out to external sources and developing firm internal units to acquire and transform external information.

Third, the study examines the role of absorptive capacity in Chile, a typical emerging economy that focuses on primary products, imitation innovation, and technology acquisition. The findings show that ACAP could play a relevant role to correct the inefficient use of R\&D that hinders the development of radical innovation and has a higher impact on international markets (Crespi and Zuñiga, 2012). Based on these findings, the application of strategic and operational knowledge in emerging economies could help them to overcome barriers to innovation such as socio-political uncertainty; lack of compliance with laws; the existence of an informal economy; and the use of interpersonal ties, networking, or partnership alliances (Geldes and Felzensztein, 2013; Ketelhöhn and Ogliastri, 2013; Geldes, Felzensztein \& Palacios, 2017; Ketelhöhn and Ogliastri, 2013).

Finally, the study highlights the specific behavior of strategic and operational absorptive capacity across industries. Comparing manufacturing and services companies, strategic ACAP is a stronger predictor of investment and technological innovation in both sectors, but operational ACAP has different effects. Alvarez et al. (2015) observed that the service sector shows very similar behavior to the manufacturing sector in innovation inputs, outputs, and productivity determinants. Therefore, operational absorptive capacity might be a more relevant variable to study differences among industries.

\subsection{Practical and policy implications}

Our findings suggest several important practical implications. Managers tend to implement strategies relying on knowledge as a resource for acquiring competitive advantage in innovation. Thus, teams should develop knowledge that integrates external sources of information - i.e., strategic ACAP - and convert this asset into operational knowledge - operational ACAP. Hence, managers should prioritize investments in the acquisition, assimilation, and transformation of knowledge, add regular interactions of employees with other departments and stakeholders (Patel, Terjesen \& Li, 2012). The key is to develop organizational learning capabilities to achieve competitive advantages.

Regarding policy, findings support the promotion of innovation programs in developing countries, especially those focused on the development of knowledge as a resource to achieve competitive advantages. In Chile, legislation related to tax incentives in R\&D and innovation has proven to be very effective. Additionally, our findings recognize differences across sectors; therefore, it is important to consider specific strategies to develop absorptive capacity and innovation depending on the economic sector. As recommended by Zahler, Goya \& Caamano (2018) to deal with obstacles to innovation, policies should be horizontal for the former and vertical for the latter. 


\subsection{Limitations and future research directions}

Despite the positive results, the study has some limitations related to the conceptualizations of strategic and operational absorptive capacity. These variables have been created through proxies derived from Chilean Innovation Surveys which are guided by the Oslo Manual (OECD, 1997). Therefore, their conceptualization might be not fully accurate, especially the operationalization of operational ACAP. Future research should consider improving the operationalization of both dimensions.

In addition, future research should analyze the effect of absorptive capacity across countries, using the CDM model. Based on Crespi and Zuñiga (2012), studies should be replicated in other Latin American countries, analyzing similarities and differences about the impact of ACAP in each country. Additionally, the analysis should integrate other non-traditional sectors such as intensive business services -KIBs- or high-tech companies.

\section{References}

Acevedo, J., \& Díaz-Molina, I. (2019). Exploration and Exploitation in Latin American Firms: The Determinants of Organizational Ambidexterity and The Country Effect. Journal of Technology Management andAmp; Innovation, 14(4),6-16. https://doi.org/10.4067/s071827242019000400006

Álvarez, R., \& Grazzi, M. (2018). Innovation and entrepreneurship in Latin America: What do we know? What would we like to know? Estudios de Economia, 45(2), 157-171. https://doi.org/10.4067/s071852862018000200157

Álvarez, R., Bravo-Ortega, C. \& Zahler, A. (2015). Innovation and Productivity in Services: Evidence from Chile, Emerging Markets Finance and Trade, 51(3), 593-611. https://doi.org/10.1080/154049 6x.2015.1026696

Álvarez, R., Bravo-Ortega, C. \& L. Navarro. (2011). Innovation, R\&D and Productivity: The Chilean Case, CEPAL Review, 104, 141-166.

Arbussà, A. \& Coenders, G. (2007). Innovation Activities, Use of Appropriation Instruments and Absorptive Capacity: Evidence from Spanish Firms. Research Policy, 36 (10), 1545-58. https://doi. org/10.1016/j.respol.2007.04.013

Autry, C.W., Grawe, S.J., Daugherty, P. \& Richey, R.G. (2010). The effects of technological turbulence and breadth on suly chain technology and adoption. Journal of Operations Management, 28 (6), 522-536. https://doi.org/10.1016/j.jom.2010.03.001

Barney, J. (1991). Firm resources and sustained competitive advantage. Journal of Management, 17 (1), 99-120. https://doi. org/10.1177/014920639101700108

Benavente, J. (2006). The Role of Research and Innovation in Promoting Productivity in Chile. Economics of Innovation and New Technology, 15(4), 301-15. https://doi.org/10.1080/10438590500512794
Brown, F., \& Guzmán Chávez, G. A. (2014). Innovation and Productivity Across Mexican Manufacturing Firms. Journal of Technology Management andAmp; Innovation, 9(4), 36-52. https://doi.org/10.4067/ s0718-27242014000400003

Chen, J., Chen, Y. \& Vanhaverbeke, W. (2011). The influence of scope, depth and orientation of external technology sources on the innovative performance of Chinese firms. Technovation, 31 (8), 362-373. https://doi.org/10.1016/j.technovation.2011.03.002

Chudnovsky, D., A. López, \& G. Pupato. (2006). Innovation and Productivity in Developing Countries: A Study of Argentine Manufacturing Firms' Behavior (1992-2001). Research Policy 35(2), 266-88. http://dx.doi.org/10.1016/j.respol.2005.10.002

Cohen, W. M., \& Levinthal, D. A. (1989). Innovation and learning: The two faces of R\&D. Economic Journal, 99(397), 569-96. https://doi. org $/ 10.2307 / 2233763$

Corrado, C., Haskel, J. \& C. Jona-Lasinio. (2011). Productivity Growth, Intangible Assets and ICT: Some International Evidence. European Commission.

Crepon, B., E. Duguet, \& J. Mairesse. (1998) Research, Innovation and Productivity: An Econometric Analysis at the Firm Level. Economics of Innovation and New Technology ,7(2), 115-58. https://doi. org/10.3386/w6696

Crescenzi, R. \& Gagliardi, L. (2018). The Innovative Performance of Firms in Heterogeneous Environments: The Interplay Between External Knowledge and Internal Absorptive Capacities. Research Policy, 47 (4), 782-95. https://doi.org/10.1016/j.respol.2018.02.006

Crespi G.A., Tacsir E. \& Vargas, F. (2016). Innovation Dynamics and Productivity: Evidence for Latin America. En Grazzi, M. \& Pietrobelli, C. Firm Innovation and Productivity in Latin America and the Caribbean: The Engine of Economic Development (pags 37-71). Inter-American Development Bank. https://doi.org/10.1057/978-1-349-58151-1_2

Crespi, G. \& Zuniga, P. (2012). Innovation and Productivity: Evidence from Six Latin American Countries. World Development, 40(2), 273-290. https://doi.org/10.2139/ssrn.1818752

Crossan, M., \& Apaydin, M. (2010). A multi-dimensional framework of organizational innovation: A systematic review of the literature. Journal of Management Studies, 47, 1154-1191. https://doi. org/10.1111/j.1467-6486.2009.00880.x

Del Carpio, J. F., \& Miralles, F. (2018). Absorptive capacity and innovation in low-tech companies in emerging economies. Journal of Technology Management andAmp; Innovation, 13(2), 1-11. https:// doi.org/10.4067/s0718-27242018000200003

Diaz-Molina, I. (2018). The Role of Strategic and Operational Absorptive Capacity in Organizational Ambidexterity. Engaged Management Scholarship Conference. Philadelphia. https://doi.org/10.2139/ssrn.3235526 
Edeh, J. N., \& Acedo, F. J. (2021). External supports, innovation efforts and productivity: Estimation of a CDM model for small firms in developing countries. Technological Forecasting and Social Change, 173, 121189. https://doi.org/10.1016/j.techfore.2021.121189

Eustace, C. (2000). The Intangible Economy: Impact and Policy Issues. En Report of the European High Level Expert Group on the Intangible Economy. European Commission.

García-Morales, V., Moreno, A. \& Llorens-Montes, F. (2007). Effects of Technology Absorptive Capacity and Technology Proactivity on Organizational Learning, Innovation and Performance: An Empirical Examination. Technology Analysis and Strategic Management, 19(4), 527-558. https://doi.org/10.1080/09537320701403540

Geldes, C., Felzensztein, C. \& Palacios, J. (2017). Technological and non-technological innovations, performance and propensity to innovate across industries: The case of an emerging economy. Industrial Marketing Management, 61, 55-66. https://doi.org/10.1016/j.indmarman.2016.10.010

Geldes, C., \& Felzensztein, C. (2013). Marketing innovation in the agribusiness sector. Academia Revista Latinoamericana de Administración, Vol. 26 No. 1, 108-138. https://doi.org/10.30954/ndp.agribusiness.2020.19

Gombau, V. \& A. Blasco. (2011). Innovation and absorptive capacity: What is the role of technological frontier?. Working Papers, Universitat Rovira i Virgili. https://doi.org/10.2139/ssrn.1973790

Harris, R. \& Le, T. (2019). Absorptive Capacity in New Zeal\& Firms: Measurement \& Importance. Science \& Public Policy, 46(2), 290-309. https://doi.org/10.29310/wp.2018.01

Harris, R. \& Li, Q.C. (2009). Exporting, R\&D, \& Absorptive Capacity in UK Establishments. Oxford Economic Papers, 61 ( 1), 74-103. https://doi.org/10.1093/oep/gpn011

Harris, R. \& Yan, J. (2019). The Measurement of Absorptive Capacity from an Economics Perspective: Definition, Measurement \& Importance. Journal of Economic Surveys, 33 (3), 729-56. https://doi. org/10.1111/joes.12296

Harris, Krenz \& Moffat (2021). The Effects of Absorptive Capacity on Innovation Performance: A Cross-country Perspective. Journal of Common Market Studies, 59(3), 589 -607. https://doi.org/10.1111/ jcms. 13108

Harris, R., \& Le, T. (2018). Absorptive capacity in New Zealand firms: Measurement and importance. Motu Working Paper, 18(1). https:// doi.org/10.29310/wp.2018.01

Haskel J. (2015). Understanding innovation better: an intangible investment approach. Asia-Pacific Journal of Accounting \& Economics, 22 (1), 13-23. https://doi.org/10.1080/16081625.2015.1010268
Howell, A. (2018). Innovation and Firm Performance in the People's Republic of China: A Structural Approach with Spillovers. ADBI Working Papers 805, Asian Development Bank Institute. https:/doi. org/10.2139/ssrn.3191735

Huang, F., Lin, K., Wu, L. \& Yu, P. (2015). Absorptive Capacity and Autonomous R\&D Climate Roles in Firm Innovation. Journal of Business Research, 68(1), 87-94. https://doi.org/10.1016/j.jbusres.2014.05.002

Janz, N., H. Loof, \& B. Peters. (2004). Innovation and Productivity in German and Swedish Manufacturing Firms: Is There a Common Story?. Problems and Perspectives in Management, 2, 184-204.

Ketelhöhn, N., \& Ogliastri, E. (2013). Introduction: Innovation in Latin America/Introducción: innovación en América Latina. Academia Revista Latinoamericana de Administración, 26(1), 12-32. doi: 10.1108/ARLA-05-2013-0037

Lau, A. \& Lo, W. (2015). Regional innovation system, absorptive capacity and innovation performance: An empirical study. Technological Forecasting and Social Change, 92(1), 99-114. https://doi. org/10.1016/j.techfore.2014.11.005

Lööf, H., Mairesse, J. \& Mohnenc, P. (2017). CDM 20 years after. Economics of innovation and new technology, 26(1-2), 1-5. https://doi.org /10.1080/10438599.2016.1202522

Lööf, H. \& Heshmati, A. (2002). Knowledge Capital and Performance Heterogeneity: A Firm-level Innovation Study. International Journal of Production Economics, 76, 61-85. 10.1016/S0925-5273(01)00147-5

Lööf, H., Heshmati, A, Asplund,R. \& Svein-Olav Nåås. (2003). Innovation and Performance in Manufacturing Industries: A Comparison of the Nordic Countries. Icfaian Journal of Management Research, 2 (3), 5-35.

Murovec, N. \& Prodan, I. (2009). Absorptive Capacity, its Determinants, and Influence on Innovation Output: Cross-cultural Validation of the Structural Model. Technovation, 29 (12), 859-72. https://doi. org/10.1016/j.technovation.2009.05.010

OECD/Eurostat (2005). Oslo Manual. Proposed Guidelines for Collecting and Interpreting Innovation Data, 3rd edition. OECD, Paris.

OECD (Organisation for Economic Cooperation and Development). (2009) Innovation in Firms: A Microeconomic Perspective, Paris: OECD.

Patel, P. C., Terjesen, S., \& Li, D. (2012). Enhancing effects of manufacturing flexibility through operational absorptive capacity and operational ambidexterity. Journal of Operations Management, 30(3), 201-220. https://doi.org/10.1016/j.jom.2011.10.004

Pérez, P., Dutrenit, G. \& Barceinas, F. (2005). Actividad Innovadora y Desempeño Económico: Un Análisis econométrico del Caso Mexicano. Indicadores de Ciencia y Tecnología en Iberoamérica, Buenos Aires, RICYT. 
Raffo, J., Lhuillery, S. \& Miotti, L. (2008). Northern and Southern Innovativity: A Comparison across European and Latin American Countries. European Journal of Development Research 20(2), 219-39. https://doi.org/10.1080/09578810802060777

Schmidt, T., \& Rammer, C. (2006). The determinants and effects of technological and non technological innovations-Evidence from the German CIS IV. Zentrum für Europäische Wirtschaftsforschung (ZEW), Mannheim.

Tello, M. (2015). Firms' Innovation, Public Financial Suort and Total Factor Productivity: The Case of Manufactures in Peru. Review of Development Economics. 19(2), 358-374. https://doi.org/10.1111/ rode. 12147

Tu, Q., Vonderembse, M.A., Ragu-Nathan, T.S., Sharkey, T.W. (2006). Absorptive capacity: enhancing the assimilation of time-based manufacturing practices. Journal of Operations Management, 24(5), 692710. https://doi.org/10.1016/j.jom.2005.05.004

Van Leeuwen, G. and \& Klomp. (2006). On the Contribution of Innovation to Multi-factor Productivity Growth. Economics of Innovation and New Technologies, 15 (4-5), 367-90. https://doi. org/10.1080/10438590500512927

Van Wijk, R., Jansen, J. J. P., Van Den Bosch, F. A. J., \& Volberda. (2012). How firms shape knowledge to explore and exploit: A study of knowledge flows, knowledge stocks and innovative performance across units. Technology Analysis and Strategic Management, 24(9), 929-950. https://doi.org/10.1080/09537325.2012.718666

Veugelers, R. (1997). Internal R\&D expenditures and external technology sourcing. Research Policy, 26 (3), 303-315. https://doi. org/10.1016/s0048-7333(97)00019-x
Vlačić, E., Dabić, M., Daim, T., \& Vlajčić, D. (2019). Exploring the impact of the level of absorptive capacity in technology development firms. Technological forecasting and social change, 138, 166-177. https://doi.org/10.1016/j.techfore.2018.08.018

World Intellectual Property Organization (WIPO). (2021). Global innovation index 2021 : tracking innovation through the COVID-19 crisis. Geneva : WIPO, 2021 World Bank. (2021). World Bank national accounts data, and OECD National Accounts data files. Retrieved from https://data.worldbank.org/indicator/NY.GDP.MKTP. CD?locations $=\mathrm{CL}$

Xia, T. \& Roper, S. (2008). From Capability to Connectivity-Absorptive Capacity and Exploratory Alliances in Biopharmaceutical Firms: A US-Europe Comparison. Technovation, 28 (11), 776-85. https:// doi.org/10.1016/j.technovation.2008.03.007

Yan, M., Yu, Y., \& Dong, X. (2016). Contributive roles of multilevel organizational learning for the evolution of organizational ambidexterity. Information Technology and People, 29(3), 647-667. https://doi. org/10.1108/itp-04-2015-0079

Zacharia, Z.G., Nix, N.W., Lusch, R.F. (2011). Capabilities that enhance outcomes of an episodic suly chain collaboration. Journal of operations Management, 29(6), 591-603. https://doi.org/10.1016/j. jom.2011.02.001

Zahler, A., Goya, D. \&Caamano, M. (2018). The Role of Obstacles to Innovation. Working Paper Series Inter-American Development Bank. https://doi.org/10.18235/0001505

Zahra, S. A., \& George, G. (2002). Absorptive capacity: A review, reconceptualization, and extension. The Academy of Management Review, 25(2), 185-203. https://doi.org/10.5465/amr.2002.6587995 
